\title{
Treatment of Expansive Clayey Soil in AL-Wahda District at Mosul City with Crushed Limestone
}

\author{
Siham I. Al-Azzo \\ Department of Geology \\ College of Science \\ Mosul University
}

(Received 16/3/2008, Accepted 7/5/2009)

\begin{abstract}
The work presented in this paper aims to the improvement of the moderately expansive clayey soil in AL-wahda district at Mosul city, by the addition of crushed limestone obtained from the waste of Masonry Factories presented in the industrial area, of east side of Mosul City. This abandoned wast material creates serious environmental problem in the area surrounding these factories requiring an urgent solution to dispose of the huge limestone belonging to Fat ha Formation. Different amounts of the crushed limestone by weight (passing sieve No. 40) were added 2, 4, 6, 8 and 10\% to the clayey soil from AL-wahda district at Mosul to reduce its expansiveness and to improve its engineering properties for many earth work construction. The results showed reduction in the plasticity of the clay and significant decrease in expansion to about $72 \%$, which gives good results for road constructions.
\end{abstract}

\section{معالجة الترية للالينية النفلخية في مي الوحة بمدينة الموطل بمسحوق الحجر الجيري}

\author{
عسهل البرلهيم العزو

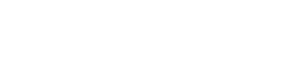 \\ كلية العلوم عالورض \\ جلمعة الموصط

\section{الملغ}

يهوف البحث إلى تعسين خواص التربة متوس طة الانتف اخ وذل لـ بإض الفة مس حوق الحج ـر

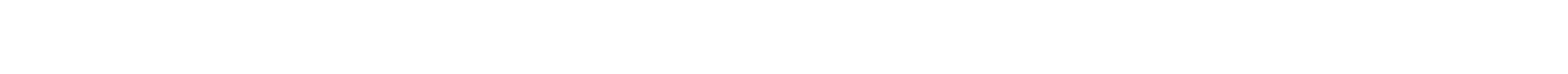

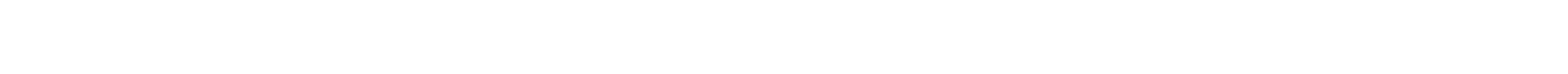

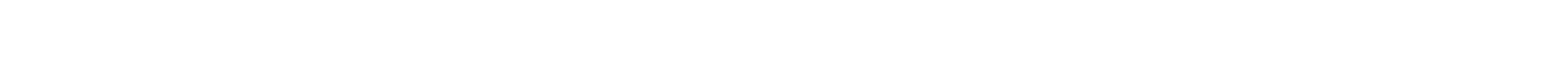


يستوجب التخلص منها. أضيفت كميلت متبلينة من مسحوق الحجر الجيري والمار من منظل رق م ( •ع)

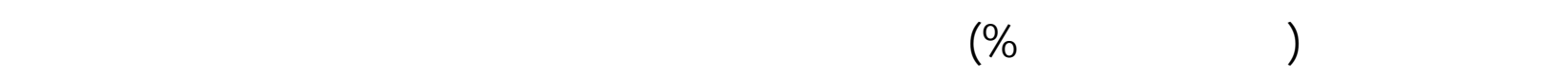

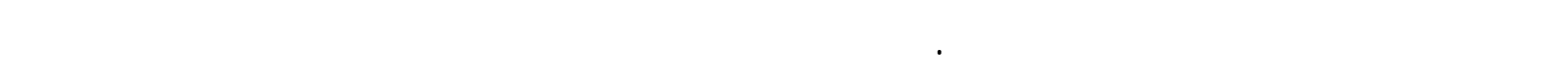
كبير لخاصيتها الانفلخية وقد بلغت قيمة الانخفاض نسبة وr \% من قيمتها قبل المعالجة . تمل هذه النتائج علملاًمهماً لإنشاء الطرق.

\section{INTRODUCTION}

Soil stabilization is a vital task not only for soft soils, but also for hazardous expansive types as well. Expansive potential of the highly plastic clays is a source of great damages and economical dispense (Gromko, 1974). The construction on subgrades requires alteration of the engineering properties of the upper soil layers, using one of soil stabilization methods (Ingles and Metcalf, 1972), or by replacement of the soil. The selection of the proper treatment method usually comes out of an economical study. The improvement of the engineering properties of soil by the addition of different compounds have been studied thoroughly by several investigators (Ingles and Metealf, 1972), (Sokolvich, 1973), ( AL- Dabbagh and Rizoo 1994) and others. Some of the compounds lead to soil improvement, while other compounds have harmful effect on the engineering soil properties, such as highly acidic chemicals (Ingles and Metealf, 1972), (Sokolvich, 1973). The most common methods employed for the stabilization of clayey soils are cement and lime stabilization (Kazdi, 1979; Sharma, 1985). These methods produce a stabilized layer of significant strength, which may not always be required in the subgrade of some structures, besides, they are costly nowadays.

Hence, this paper describes an investigation on the addition of by product crushed limestone which is abandoned in huge quantities, to expansive clays, to improve their engineering properties. This waste material byproduct creates serious environmental problems nowadays in the Masonry factories surrounding areas.

\section{1- Limestone}

\section{MATERIALS}

Limestone is the most widely occurring rock in Iraq and particularly in Mosul area, it is belonging to Lower Fars formation (Fat ha) - Middle Miocene, extensively used in constructional works thousand years ago. Assyrian archeological sites are some of the famous examples in this respect. Many types of limestone from different geological ages outcrop can be found in this area. The most preferred type for constructional wise is the limestone that belongs to the Fat'ha Formation, as it is of highly fossiliferous in nature which gives a fragmental appearance as well as it can be cut easily in different shapes and sizes (Fig. 1).

\section{2- Clay}

The clay in at Mosul area are generally moderately to high expansive potentials varies between $(4.5-15 \%)$ for remolded samples and $(2.4-9 \%)$ for undisturbed samples (AL-layla and Al-Ashou , 1985 ). Many studies showed that the index properties can be used to estimate the expansiveness of these soils, ( Holts and Gibbs, 1956 ), such estimation is more convenient for remolded rather than undisturbed soil. The swelling potential of the soil can also 
be estimated with the help of activity of the soil and the percentage of clay size particles which can be used as measure for the amount of volume change (Seed, et al., 1962). The clay used in this study obtained from $(1.0-1.5) \mathrm{m}$ deep test pits located at AL- Wahda district at Mosul, (Fig. 1), It is in general of light brown colored clay with variable thickness belonging to recent age. The top clay soils have, the following properties : L .L. $=51 \%$, P.I. $=24 \%$. Thus the soil is classified as $(\mathrm{CH})$ according to the Unified Classification System and desribed as "Inorganic clay of high plasticity" (Fig. 2).

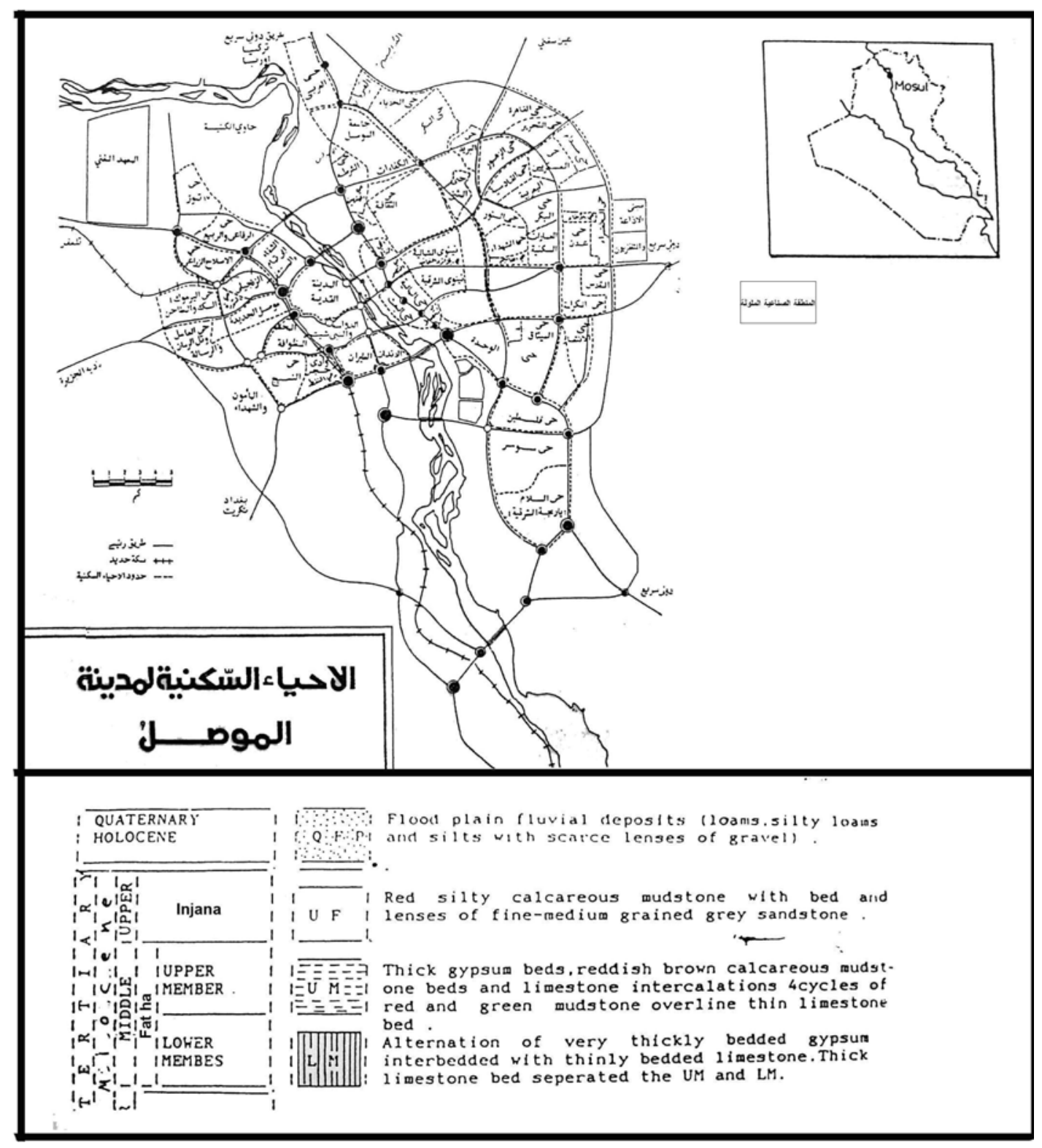

Fig. 1: Location and lithologic column of Mosul.

The activity of the soil is $(0.64-0.77)$, the linear shrinkage ( 1 r. $9-14.8 \%)$, swelling according to the formula presented by Seed, et al., (1962) in $5.56 \%$ and it can be classified as medium expansive soil following the classification suggested by (Holts and Gibbs, 1956). The percentage of clay size particles $(\leq 2 \mu)$ is $40-42 \%$ (Fig. 3 ). The clay minerals were identified by X-Ray Diffraction Analysis. The result shows that the clay minerals are: Kaolinite, Illite, Moutmorillonite and chlorite, the non-clay minerals are; 
Quartz, Calcite and Gypsum (AL-Dabbagh, 2000). Cation Exchange Capacity (C.E.C) is 41 milliequivalent /100 gm. of medium expansion as compared with value of Montmorillonite type (Grim, 1986). There was a significant change in the engineering properties of the treated soil due to the addition of $(\mathrm{Ca} \mathrm{CO} 3)$ as discussed in the following paragraphs.

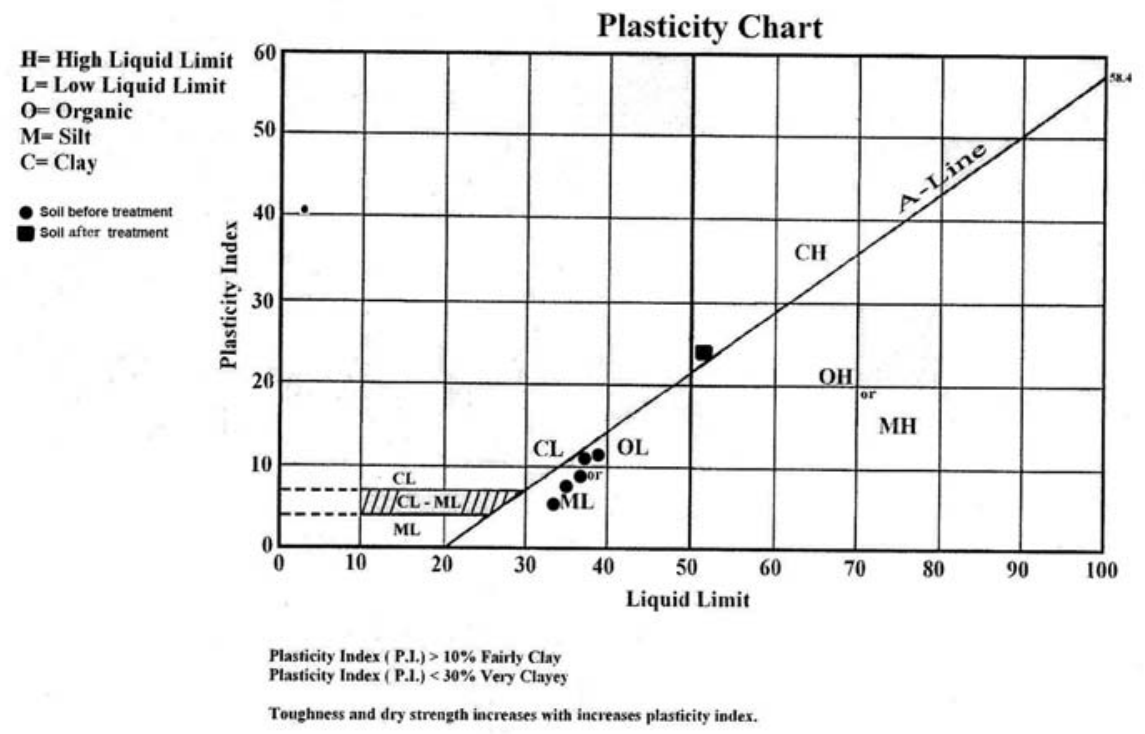

Fig. 2: Plasticity chart used for classification of fine-grained soil.

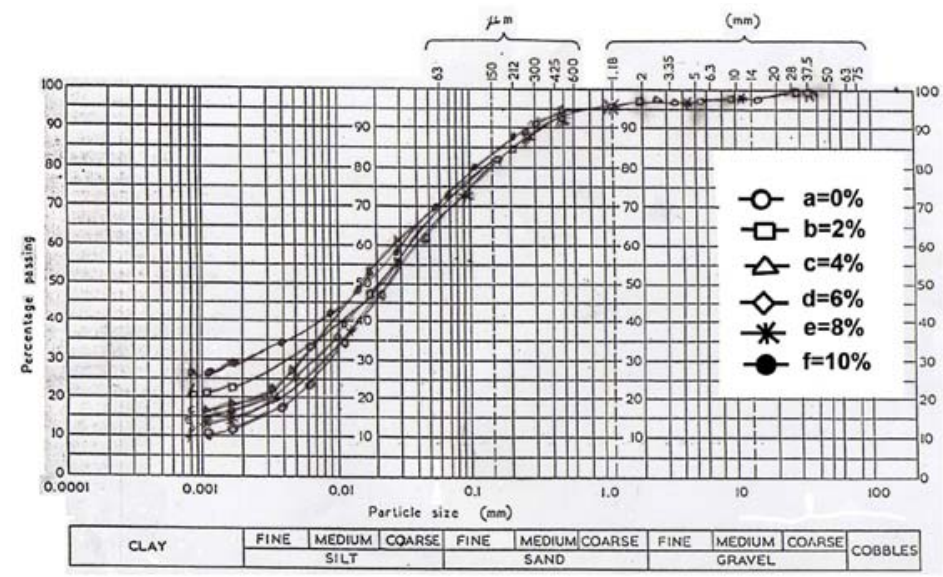

Fig. 3: Grain size distribution diagram.

\section{DISCUSSION OF RESULTS}

\section{Index Properties}

\section{1- Atterberg limits}

The consistency limits of the treated soil were determined after being mixed with $(2,4,6,8$ and $10 \%)$ of the crushed limestone. The results of the treated and untreated samples are given in Table (1). It can be noticed that the classification of the soil altered from $(\mathrm{CH})$ to $(\mathrm{ML})$ after treatment (Fig. 2). 
Table 1:Comparison of consistency limits.

\begin{tabular}{|c|c|c|c|c|c|c|}
\hline $\begin{array}{c}\text { \% Crushed limestone } \\
\text { passing sieve No.40 }\end{array}$ & 0 & 2 & 4 & 6 & 8 & 10 \\
\hline Liquid Limit (L.L.)\% & 51 & 39 & 38.5 & 38 & 37 & 35 \\
\hline Plastic Limit (P.L.)\% & 27 & 27.5 & 28 & 29 & 29 & 30 \\
\hline Plasticity Index (P.I.)\% & 24 & 11.5 & 10.5 & 9 & 8 & 5 \\
\hline Linear shrinkage 90 & 13.38 & 12.93 & 12.6 & 12.2 & 11.9 & 10.3 \\
\hline
\end{tabular}

\section{2- Linear shrinkage}

Table (1) show that the linear shrinkage reduced from 13.38 to 10.3 by the addition of the crushed Lime stones. It is believed that this change in physical properties of the clay partly resemble the same effect of clay stabilization by sand addition as the increase of sand in certain amount of soil, the percentage of clay within this amount will be reduced, and consequently, the properties will be changed (Al-Ashou and Al-Khashab, 1993), and partly by the effect of the presence of "Ca" ions as obtained from pervious study (Al-Ashou and Al-Khashab, 1994). These ions combined with or absorbed by clay, creating an increase in the flocculation tendency of the soil fluid. This yields to decrement of the repulsive forces. These changes continue up to certain fixation point. This addition leads to improvement of soil workability, but not to an increase in strength (Bell, 1996). The addition in excess of the fixation point is utilized in the cementation process. As a result, the clay practices will readjust themselves into more stable configuration.

\section{Grain Size Analysis:}

Table (2) and Figure (3) describe sieves and hydrometer analysis result. It can be shown that the clay size particles $(<=2 \mathrm{~mm})$ decreased with the increase of crushed Limestone addition, while the percent of silt size particles $(2-7.4 \mathrm{~mm})$ increased. This phenomenon is due to the fluctuation of clay particles to the silty size resulting from the presence of $\mathrm{Ca}$ and consequently a decrease in the double water layer occurred.

Table 2: Comparison of the grain-size analysis results

\begin{tabular}{|c|c|c|}
\hline $\begin{array}{c}\text { \%Crushed limestone } \\
\text { passing sieve No.40 }\end{array}$ & (\%) Clay & (\%) Silt \\
\hline 0 & 40 & 53 \\
\hline 2 & 36 & 57 \\
\hline 4 & 32 & 61 \\
\hline 6 & 30 & 63 \\
\hline 8 & 29 & 64 \\
\hline 10 & 24 & 69 \\
\hline
\end{tabular}

\section{Modified Compaction Test:}

The compaction was done by locally manufactured tool especially made to resemble the Harvard Miniature Compaction Tool (Fig. 4) on soil samples mixed with $(0,2,4,6,8$ and $10 \%$ ) of crushed limestone addition. The samples were compacted at different moisture contents, to obtain the moisture-density relationship. The results are plotted in Figure (5) 
and summarized in Table (3). This clarifies the difference due to treatment. It can be noticed that the dry density increases with the crushed Limestone amount up to $4 \%$, then it tends to decrease below this amount. It can be said that a (4\%) addition is the optimum, which gives a maximum density.

Fig. 4: Compaction tools.

Fig. 5: Modified procter compaction test result. 
Table 3: Comparison of the results of the modified compaction with the unconfined compressive strength.

\begin{tabular}{|l|c|c|c|c|c|c|}
\hline $\begin{array}{l}\text { \% Crushed limestone passing } \\
\text { sieve No.40 }\end{array}$ & 0 & 2 & 4 & 6 & 8 & 10 \\
\hline Max. Dry Density gm/cc (8 d) & 1.66 & 1.71 & 1.72 & 1.71 & 1.71 & 1.7 \\
\hline $\begin{array}{l}\text { Optimum Moisture Content } \\
\text { (O.M.C.)\% }\end{array}$ & 19.7 & 19.0 & 18.5 & 18.8 & 19.5 & 20 \\
\hline $\begin{array}{l}\text { Unconfined Compressive } \\
\text { Strength Kg/cm }\end{array}$ & 2.0 & 3.04 & 5.09 & 4.19 & 3.46 & 2.25 \\
\hline
\end{tabular}

\section{Unconfined Compressive-Strength:}

The results were presented in Table (3) which shows that 4\% addition gives maximum amount of the (U.C.S.) (See Fig. 6). For the comparison study of (U.C.S), the cures of Fig. 3 were used to maintain the same dry unit weight of all soil samples with different moisture contents. Two soil samples for each percentage of the added crushed limestone were prepared using a compaction tool (Fig. 4).

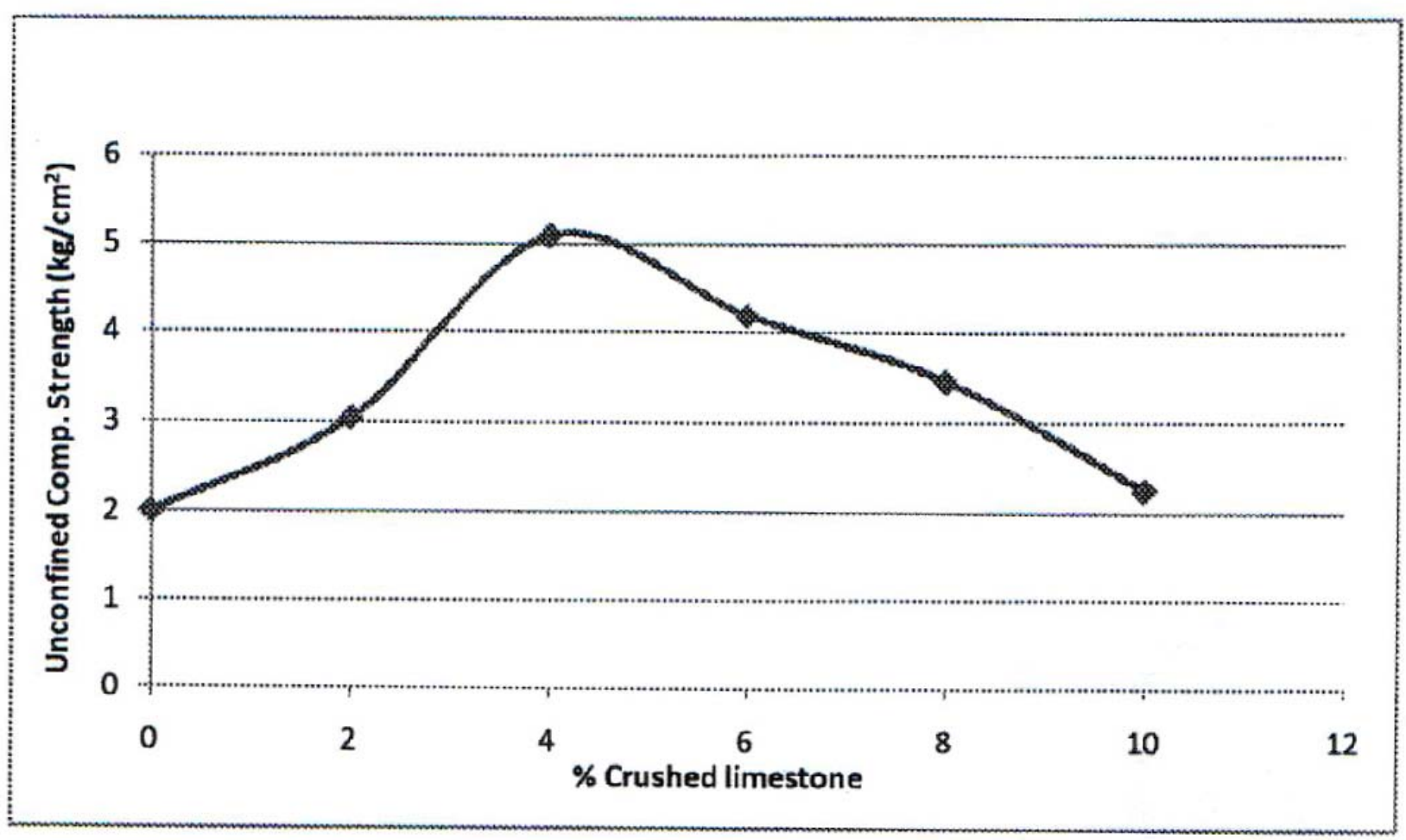

Fig. 6: Effect of lime content on the unconfined compressive strength of soil. 


\section{Swelling Properties:}

For the purpose of this study swelling pressure and free swell tests were conducted on samples treated with $(2,4,6,8$ and 10\%) crushed limestone the results are presented in Table (4).

Table 4:Swelling properties..

\begin{tabular}{|l|c|c|c|c|c|c|}
\hline $\begin{array}{l}\text { \% Crushed limestone } \\
\text { passing sieve No.40 }\end{array}$ & 0 & 2 & 4 & 6 & 8 & 10 \\
\hline Swelling Pressure Kg/cm 2 & 1.95 & 1.4 & 0.86 & 0.69 & 0.59 & 0.55 \\
\hline Free Swell (\%) & 4.76 & 3.3 & 3.0 & 2.6 & 1.4 & 1.3 \\
\hline
\end{tabular}

All samples were prepared under initial water content of $15 \%$ and dry density 1.69 $\mathrm{gm} / \mathrm{cc}$ for comparison purposes. The samples preparation was conducted in the tool shown in Figure (7). The test results show that the swelling pressure and percentage of swell decreased considerably with the increase of crushed stone amounts. Figure (8) showed that swelling pressure is always decreases with the increasing of crushed stone amount, while the percentage of swell has another behavior as the curve concave after the value of ( $4 \%$ crushed limestone) which represents the optimum value.

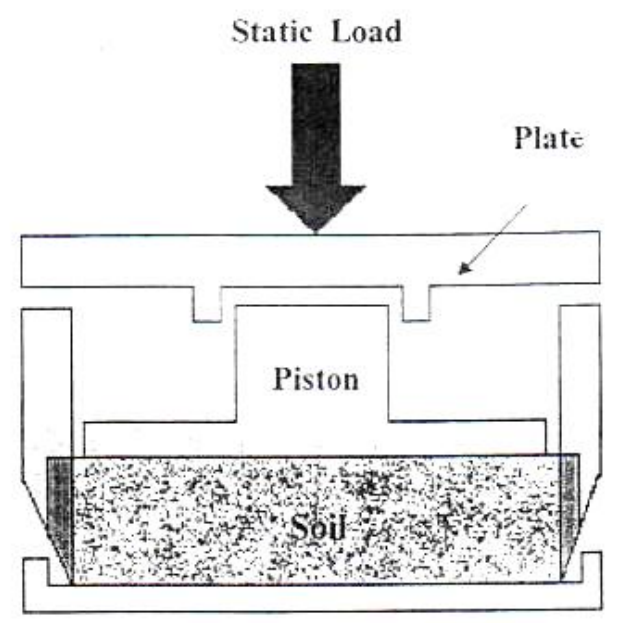

Fig. 7: Soil samples preparation tool for swelling tests. 


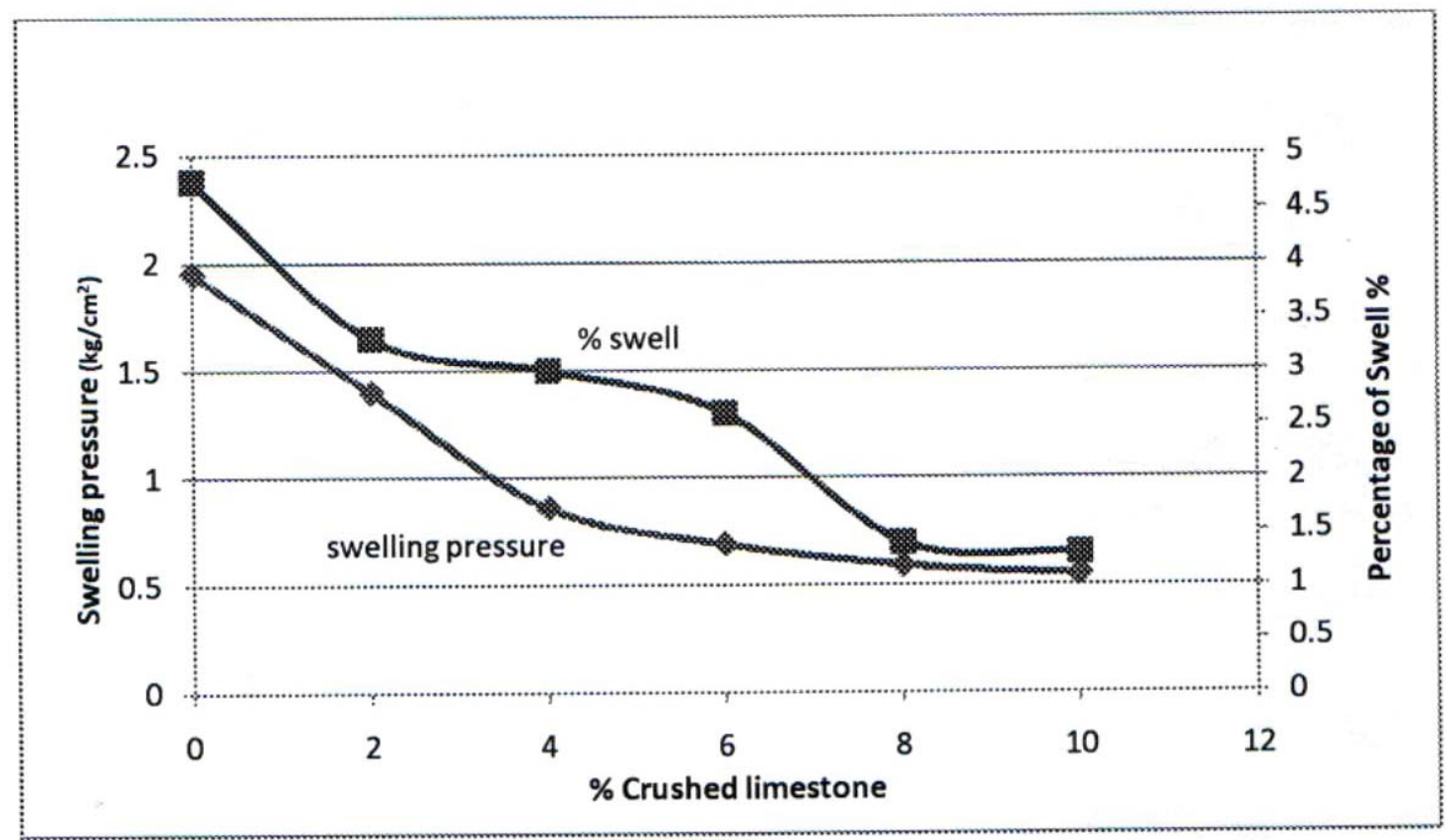

Fig. 8: Effect of lime content on the swelling properties of soil.

\section{Results}

The following findings can be concluded from the work:

1- The index properties of the clay were changed by the addition of the crushed stone towards silty characteristics.

2- The reduction of the index properties towards less plastic nature means that there will be pronounced reduction in the swelling potentials.

3- The maximum unconfined compressive strength was gained by $4 \%$ crushed stone addition.

4- The continuous addition of crushed stone cause a decrease in clay swelling pressure and the amount of free swell.

\section{REFERENCES}

Al-Ashou, M.O. and Al-Khashab, M.N. 1993. Treatment of Expansive Clay with Potassium Chloride. Rafidain Eng. Journal, Mosul University, Vol., No. 2, pp. 17-30.

Al-Ashou, M.O. and Al-Khashab, M.N. 1994. Effect of Acid Rain on the Engineering Properties of Clay Soil. Rafidain Eng. Journal, Mosul University, Vol.2, No. 2, pp. 2-15.

Al-Dabbagh, Th.H. and Al-Rizzo, H.M, 1994. A Proposed Soil Index for Soil Stabilization Evalution. Environ.Sci Health, A 29(8), pp. 1531-1540.

Al-Dbbagh, A.W.N. 2000. Study of Expansive Behavior of Clay Using Soil Suction as Applied to Wahda District in Mosul Area. Ms. Sc. Thesis, Mosul University. Eng. College

Al-Layla, M.T. and Al-Ashou, M.O. 1985. Swelling Properties of Mosul Clay. Proc. Iraqi Conf. on Eng., Baghdad-Iraq, pp. 18-23.

Bell, F.G. 1996. Lime Stabilization of Clay Mineral and Soil.Eng. Geol. 42, Dept. of Geol. and App Geol. University of Natal, South Africa, pp. 223-237.

Grim, R. 1986. Applied Clay Mineralogy. $2^{\text {nd }}$ Edi., Mc Graw Hill-New Yourk. pp7-47. 
Gromko, Gerald, J. 1974. Review of Expansive Soils. Journal of the Geotechnical Engineering Division, ASEC, Vol. 100, No. G.T, 6, June, pp. 667- 685.

Holts, W.G. and Gibbs, J.H. 1956. Engineering Properties of Expansive Clay. ASCE Tranactions, Vol. 121, pp. 641.

Ingles, O.G. and Metcalf, J.B. 1972. Soil Stabilization (Principle and Practice), Butterworth, Sydney, pp. 165-186.

Kazdi, A. 1979. Stabilized Earth Roads, The English Edition, Akademia Kiado, Budapest, Hungary.

Seed, H.B., Wood Ward, R.J. and Lundgren, R., 1962. Prediction of Swelling, Potential for Compacted Clays. Proc. of ASCE soil Mech. And Found. Div.99, No. Sm3, pp. 53-86.

Sharma, S.K1985. Principles, Practice and Design of Highway Engineering. 5Cand and Company Ltd. Ram Nagar, New Delhi, 110055.

Sokolvich, V.E. 1973. Acid as Chemical Stabilization of Clay Soils. Scientific Research Institute of Foundations Osnovaniya, Fundamentally I MechanikaGruntov, No. 4, pp. 22- 23, July -August (1973), Translated from Russian by (c/b) ConsultantBureau, New York, Jan. (1974), pp. 271-273. 